\title{
THE INFLUENCE OF SPEEDING ON MOTORBIKE RIDERS ON MEDAN
}

\author{
Pengaruh Speeding Pada Pengendara Sepeda Motor di Medan
}

\author{
Irmawati \\ Faculty of Psychology \\ University of Sumatera Utara \\ Jl. Dr. Mansyur No.7 \\ Medan, North Sumatra \\ irmawati@usu.ac.id
}

\author{
Meutia Nauly \\ Faculty of Psychology \\ University of Sumatera Utara \\ Jl. Dr. Mansyur No.7 \\ Medan, North Sumatra \\ meutia@usu.ac.id
}

\author{
M. Ridwan Anas \\ Faculty of Psychology \\ University of Sumatera Utara \\ J1. Dr. Mansyur No.7 \\ Medan, North Sumatra
}

\begin{abstract}
Based on data and previous studies on the condition of the city of Medan. As a large city and the high accident rate. The purpose of this study is to study the effect of speed as a factor in the causes of traffic accidents. Which is related to the behavior of drivers in terrain cities, especially on national road sections with a specification's minimum 4/2 D. The location studied in six road sections that are considered to represent 14 road segments in accordance with the scope of the study area, namely the road (1) Jalan Industri, (2) Jalan Gagak Hitam, (3) Jalan Ngumban Surbakti, (4) Jalan Sisingamangaraja, (5) Jalan. Yos Sudarso, (6) Jalan A.H. Nasution. The analysis uses a t-test for a comparative test. Behavioral studies use a mixed design approach that is carried out in parallel, through FGD and on-line surveys $(\mathrm{N}=200)$ using a scale that measures attitudes, beliefs, subjective norms of people around the driver, perceptions of the risk of speeding behavior and demographic questions. The results of the study show that there is an influence of the average speed of roads at the accident rate of national roads. The attitudes and beliefs of research participants tended to be opposed to 'speeding' behavior. Subjective norms of people around the driver as well as showed negative attitudes. Research participants also display high-impact perceptions of the likelihood of accidents caused by their 'speeding' behavior. Based on the regression analysis, it can be concluded that there is a meaningful relationship between participants' attitudes towards' speeding 'and subjective norms (attitudes and beliefs of the surrounding environment towards' speeding'.
\end{abstract}

Keywords: behavior of drivers, speeding, t-test for comparative test

\begin{abstract}
Abstrak
Berdasarkan data dan kajian sebelumnya mengenai kondisi kota Medan sebagai kota besar dan tingkat kecelakaan yang termasuk tinggi, maka tujuan dari penelitian ini adalah melakukan kajian pengaruh kecepatan sebagai faktor penyebab kecelakaan lalu lintas, yang terkait denganperilaku pengemudi di kota medan khususnya pada ruas jalan nasional dengan spesifikasi minimal 4/2 D. Lokasi yang diteliti merupakan 6 ruas jalan yang dianggap mewakili 14 ruas jalan sesuai dengan lingkup wilayah studi, yakni (1) Jalan Industri, (2) Jalan Gagak Hitam, (3) Jalan Ngumban Surbakti, (4) Jalan Sisingamangaraja, (5) Jalan. Yos sudarso, dan (6) Jalan A.H. Nasution. Analisis menggunakan t tes untuk uji banding. Kajian perilaku menggunakan pendekatan mixed design yang dilakukan secara paralel, melalui FGD dan survey on line $(\mathrm{N}=200)$ dengan survey on line menggunakan skala yang mengukur sikap, belief, norma subyektif dari orang-orang di sekitar pengendara, persepsi terhadap resiko perilaku speeding dan pertanyaan demografik. Hasil studi menunjukkan terdapat pengaruh kecepatan rata-rata ruas jalan terhadap tingkat kecelakaan ruasruas jalan nasional. Sikap dan belief partisipan penelitian cenderung negatif terhadap perilaku 'speeding', norma subyektif orang-orang di sekitar pengendara juga menunjukkan sikap yang negatif. partisipan penelitian juga menampilkan persepsi yang mengarh ke tingggi terhadap kemungkinan kecelakaan yang diakibatkan oleh perilaku 'speeding' yang mereka lakukan. Bedasarkan analisis regresi diperoleh kesimpulan bahwa ada hubugnan yang berarti antara sikap partisipan terhadap 'speeding' dengan norma subyektif (sikap dan belief dari lingkungan sekitar terhadap 'speeding'.
\end{abstract}

Kata kunci: perilaku pengemudi, speeding, t-test untuk uji banding 


\section{INTRODUCTION}

Traffic accidents are a leading indicator of the level of road safety. In the developed country's road safety, problems are very much considered to reduce the number of traffic accidents and the number of traffic accident victims who occur. Traffic accidents tend to increase and are still the main problem in the implementation of road transportation in Indonesia, the number of road transport accidents in 2015 obtained data that the number of accidents occurred 98,970 cases, with the death toll 26,495 people. The number of harmed victims was 23,937 people, and the number of 110,714 minor injuries (Korlantas Polri, 2016).

Medan, as the capital of North Sumatra Province, has a function as a center for social, economic, and government activities. The population of Medan City in 2017 reached $2,247,425$ people with a population growth rate of $0.81 \%$, with an area extending 265.10 $\mathrm{km}^{2}$, the population density reached 8,478 people $/ \mathrm{km}^{2}$ (BPS, 2018), along with the increase in the population of each year, then vehicle ownership growth rate was also higher at $+9.8 \%$, with the most significant proportion of users of road transport is dominated by private vehicle users $(94.20 \%)$, where the motorcycle is the majority of types of users of private vehicles $(86.29 \%)$, indirectly will increase the risk of growing traffic problems, such as congestion and accidents.

The number of traffic accidents in Medan City in 2017 was recorded at 1,233 incidents (BPS, 2018). The most significant contributors to accidents are motorbike riders, and the speed factor is the most common cause of accidents (Romadhona, 2017). Previous research stated that the factors that caused accidents were speed (Maya, 2000). Sugiyanto et al. (2014) noted that the main factors that caused the increasing number of traffic accidents were the growth of motor vehicle ownership, especially motorbikes. Motorbikes are the vehicle most involved in accidents (Sugiyanto and Santi, 2015).

Accidents can be caused by factors, many traffic accidents caused by a combination of factors, the behavior of driver or pedestrian roads, awful weather conditions, and a wrong view (Pignataro, 1993). The purpose of this study is to study the effect of speed as a factor causing traffic accidents related to the behavior of drivers in the city of Medan, especially on national road segments with minimum specifications of 4/2 D.

Site under consideration is part of the function of a primary arterial road (national road), 14 national roads are included in the scope of the study area. Data collection is done at six roads that are supposed to represent, among other things: (a) Jln. Industri/Jln. Gagak Hitam, (b) Jln. Ngumban Surbakti, (c) Jln. A.H. Nasution, (d) Jln. Sisingamangaraja, (e) Jln. Asrama, and (f) Jln. Yos Sudarso

\section{LITERATURE STUDIES}

\section{Review of Regulations Related to Traffic Accidents}

Accidents according to traffic laws and road transport no. 22 of 2009 means "Traffic Accident is an event on an unexpected and accidental road involving a vehicle with or without another road user which results in human casualties and/or property losses."

The Law in Indonesia (UUD) No. 38 of 2004 concerning Roads mandate that the operation of public roads is carried out after being declared to have met the technical and 
administrative feasibility requirements. In addition to the demands for reliability and security, the implementation of national roads must be capable of provide safety guarantees for its users and must also be able to provide legal certainty for its operators, as stated in Article 8 and Article 22 of Law 38/2004 on Roads and Law 22/2009 on Traffic and Road Transportation (LLAJ).

Traffic accidents that occur on the road can vary, both toll roads and non-toll roads. Nontoll roads also have different characteristics between inner-city roads, inter-city roads, and inter-provincial roads (Manalu, 2013).

\section{Classification of Functions and Class of Roads}

Refer to the Guidelines for Determining Classification of Road Functions in Urban Areas (DG of Highways, 1990) and RI PP No. 43 of 1993 concerning Road Traffic and Infrastructure, and the road can be classified based on its role, function, and authority. Road classification is based on the level of service of traffic flow (mobility) and service of road access to the surrounding land use (accessibility). The grouping of roads based on their roles is as follows:

1. Arterial Road, which is a road that serves long-distance transportation, with high average speed and the number of access roads, is efficiently restricted.

2. Collector Road, which is a road that serves the transportation of collection and distribution with characteristics, is a short-distance trip, with low average speed and a limited number of entrances.

3. Local Road, which is a road that serves localized transportation with characteristics of short-distance travel, the average speed is low with an unlimited number of entrances.

The division of road functions is based on the role of its distribution services in an area that binds and connects the growth center with the region that is under the influence of its services in a hierarchical relationship. According to the role of its distribution services, the road network system consists of:

1. The primary road network system, namely the road network system with the role of distribution services for the development of all regions at the national level with all the knots of distribution services in the form of cities.

2. The secondary road network system, namely the road network system with the role of distribution services for the community in the city.

The division of road status is based on the authority of its guidance. In this case, it is more inclined to the obligations in its financing, where the road for national road construction is delegated to the Ministry of Public Works.

\section{Traffic Behaviour}

This study will use two psychological concepts, first is Risk-Taking Culture, including Belief, Attitude, Intention, and subjective norms (Eiksund, 2009); second is Risk Perception, namely the perception of the risk of possible traffic accidents Cohen et al. (1995, in Machin \& Sankey, 2007).

Attitudes, perceptions of risk, and behavior are found to be related to the safety of the traffic, according to the Reason Action Theory and Theory of Planned Behavior (Eiksund, 2009; Iversen and Rundmo, 2004). Risk perception is a subjective experience of the risk of possible traffic accidents (Deery, 1999); understanding of risk negatively associated with 
risky behavior, in general, the higher the level of risk perception towards an appropriate response the more likely the individual is to carry out this behavior.

Risk homestead theory states that driving behavior at risk simultaneously raises costs and benefits. Related to driving behavior, the cost/cost side is things that are not desirable, in this case, including ticketing, injury, or fatalism from risky behavior. Besides the cost side, it also involves benefits such as pleasure when driving or saving time to reach the destination. In hazardous behavior in driving, unfortunately, drivers often fail to perceive adequate costs/costs for the long term. They prefer unsafe behavior, such as speeding (Wong, Chung and Huang, 2010). So in this study will be described motorcycle riding behavior and mutual relations between various variables.

\section{METHODOLOGY}

\section{Hypothesis Approach}

This study uses a hypothesis test; the analysis was carried out usually to use the Independent sample T-test method, which is a type of statistical test that aims to compare the average of two groups that are not paired or not interrelated (different subjects). In this study, the two data groups had the same variant so that the Independent T-test value was read as Equal variance. The formula of the Independent T-test with variance homogeneity is as follows (Kennedy, 1976):

$$
F=\frac{S_{1}^{2}}{S_{2}^{2}}
$$

Notes: $\mathrm{F}=\mathrm{F}$-Count

$$
\begin{aligned}
& S_{1}=\text { Variance } \\
& S_{2}=\text { Variance }
\end{aligned}
$$

Data are expressed as having the same variance if F-Count unequal variance if $\mathrm{F}$ Calculate> F-Table. The form of the variance of the two data groups will affect the standard error value, which will finally distinguish the test formula.

\section{Quantitative Data and Qualitative Traffic Behavior}

On line survey (N: 200) uses a scale that measures attitudes and beliefs about speeding behavior, subjective norms of people around drivers, perception of the risk of speeding behavior, and demographic questions, such as age, gender, recent education, fast driving, sanctions against speeding violations. Qualitative data was obtained through a focus group discussion of two groups of 10 people who claimed to often 'speed up' in motorbike driving.

\section{ANALYSIS RESULT}

\section{Accident Data on the Medan City National Road Segment}

Based on the results of the analysis of traffic accident data in Medan in 2018 for the 6 road sections, it was obtained that 115 had occurred accident cases with the number of dead 264 people. The amount and victims of traffic accidents are shown in the following table. 
Table 1. Traffic accident data on Medan City National Roads in 2018

\begin{tabular}{|c|c|c|c|c|c|}
\hline \multirow[b]{2}{*}{ No. } & \multirow[b]{2}{*}{ Road Segment Name } & \multirow[b]{2}{*}{ Number of Accident } & \multicolumn{3}{|c|}{ Victim } \\
\hline & & & $\begin{array}{c}\text { Die } \\
\text { (MD) }\end{array}$ & $\begin{array}{c}\text { Seriously } \\
\text { Injured } \\
\text { (LB) }\end{array}$ & $\begin{array}{c}\text { Minor } \\
\text { Injured } \\
\text { (LR) }\end{array}$ \\
\hline 1 & Jln. Industri/Jln. Gagak Hitam & 27 & 6 & 15 & 17 \\
\hline 2 & Jln. Ngumban Surbakti & 21 & 5 & 11 & 14 \\
\hline 3 & Jln. A.H. Nasution & 10 & 3 & 5 & 9 \\
\hline 4 & Jln. Sisingamangaraja & 33 & 11 & 15 & 12 \\
\hline 5 & Jln. Asrama & 12 & 1 & 4 & 9 \\
\hline 6 & Jln. Yos Sudarso & 12 & & 5 & 8 \\
\hline
\end{tabular}

Source: Polresta Medan, 2018

From the table above, it can be seen that the number of accidents in 2018 was 115 incidents, of which there were 81 accidents involving motorcycle users (70.4\%).

\section{Analysis of Traffic Volume of National Roads in the City of Medan}

Degree of Saturation is one of the performance indicators of a road in urban areas. But for road users, the degree of genuineness is not something that can be felt directly or seen in real terms. Degree of saturation (degree of saturation= DS) is defined as the ratio of traffic flow (pcu/hour) to capacity (pcu/hour) on a particular road section, which is used as the first factor in determining the performance level intersections and roads.

From the data obtained, both primary and secondary data gathered Q (in veh/hour, $\mathrm{pcu} /$ hour), then $\mathrm{VCR}=\mathrm{Q} / \mathrm{C}$ is derived from the calculation. The following is a summary of the degree of saturation of each review road section.

Table 2. The Degree of Saturation (DS) recapitulation

\begin{tabular}{llcccccc}
\hline $\begin{array}{c}\text { Segment } \\
\text { Code }\end{array}$ & Road Segment Name & $\begin{array}{c}\text { Length } \\
(\mathbf{k m})\end{array}$ & $\begin{array}{c}\text { Width } \\
(\mathbf{m})\end{array}$ & $\begin{array}{c}\text { Direc- } \\
\text { tion }\end{array}$ & $\begin{array}{c}\text { Capacity } \\
(\mathbf{p c u} / \mathbf{h})\end{array}$ & $\begin{array}{c}\text { Volume } \\
(\mathbf{p c u} / \mathbf{h})\end{array}$ & DS \\
\hline 007.11 & Jln. Industri/Jln. Gagak Hitam & 5.16 & 15.54 & $\mathrm{~N}$ & 3,058 & 2,800 & 0.916 \\
\hline 007.12 & Jln. Ngumban Surbakti & 3.44 & 16.51 & $\mathrm{~N}$ & 3,058 & 2,594 & 0.848 \\
\hline & & & & $\mathrm{O}$ & 3,058 & 2,603 & 0.851 \\
\hline 007.13 & Jln. A.H. Nasution & \multirow{2}{*}{5.37} & 17.43 & $\mathrm{~N}$ & 3,058 & 3,430 & 1.122 \\
\hline & & & & $\mathrm{O}$ & 3,058 & 3,491 & 1.141 \\
\hline 007.14 & Jln. Sisingamangaraja & 4.98 & 16.11 & $\mathrm{~N}$ & 2,871 & 4,091 & 1.425 \\
\hline & & & & $\mathrm{O}$ & 2,871 & 3,496 & 1.218 \\
\hline 009.11 & Jln. Asrama & 11.48 & 15.60 & $\mathrm{~N}$ & 3,058 & 2,020 & 0.661 \\
\hline
\end{tabular}


The results of data analysis of Degrees of Saturation represented by VCR values of national road segments have VCR values> 0.4, and VCR values>0.7, indicating the performance of roads already in a jammed condition, especially during rush hour morning and evening.

\section{Speed Analysis of National Road in Medan}

The survey was carried out using a speed gun as a vehicle speed recorded. Speed Gun is a tool that helps to determine the speed of objects that slide/move, such as cars, motorcycles, ships, balls, etc. Whereas the speed for each segment is obtained from the analysis with the 85 Percentile Speed Method. The purpose of this method is to find out the speed limit that matches the vehicle speed data that passes through the road section being reviewed. In the following table, you can see a resume of the results of the speed survey for each section.

Table 3. Resume data from speed per hour

\begin{tabular}{clcccccc}
\hline $\begin{array}{c}\text { Segment } \\
\text { Code }\end{array}$ & Road Segment Name & Date & Time & $\begin{array}{c}\text { Speed } \\
\text { Data }\end{array}$ & $\begin{array}{c}\text { Lowest } \\
\text { Speed }\end{array}$ & $\begin{array}{c}\text { Highest } \\
\text { Speed }\end{array}$ & $\begin{array}{c}\text { 85 }^{\text {th }} \text { Speed } \\
\text { Percentile }\end{array}$ \\
\hline 007.11 & Jln. Gagak Hitam & $5 / 29 / 2019$ & 14.00 & 300 & 22 & 70 & 50 \\
\hline 007.12 & Jln. Ngumban Surbakti & $5 / 28 / 2019$ & 10.00 & 300 & 20 & 70 & 49 \\
\hline 007.13 & Jln. A.H. Nasution & $5 / 29 / 2019$ & 12.30 & 300 & 21 & 60 & 44 \\
\hline 007.14 & Jln. Sisingamangaraja & $5 / 29 / 2019$ & 10.00 & 300 & 17 & 59 & 40 \\
\hline 009.11 & Jln. Asrama & $5 / 29 / 2019$ & 15.30 & 258 & 20 & 70 & 49 \\
\hline 009.15 & Jln. Yos Sudarso & $5 / 28 / 2019$ & 16.00 & 278 & 22 & 53 & 39 \\
\hline
\end{tabular}

From the table, it can be seen the speed ranges for each road section and from the results of the analysis it can be seen that the speed of the vehicle that is often used by the driver ( 85 percentile speed) ranges from $39 \mathrm{~km} / \mathrm{h}$ to $50 \mathrm{~km} /$ hour. This test used a significance level alpha of $95 \%$ so that the value of $\mathrm{Z}$ obtained from the reading of the normal distribution table of 1.645 .

\section{Result of Statistics}

Hypothesis testing is a temporal test of a situation. In this study, the situation is the effect of the speed of the accident rate on national road segments.

The hypothesis in the analysis is as follows:

- Ho: there is no influence on the average speed of the road to the level of the accident of national road segments.

- Ha: there is an influence on the medium speed of the road to the level of the accident of national road segments. 
Table 4. T-Test Result

\begin{tabular}{lcc}
\hline & Kecepatan & Kecelakaan \\
\hline Mean & 45.16666667 & 19.16666667 \\
\hline Variance & 23.76666667 & 88.56666667 \\
\hline Observations & 6 & 6 \\
\hline Pearson Correlation & 0.003632699 & 0 \\
\hline Hypothesized Mean Difference & 5 & \\
\hline Df & 6.017830649 & \\
\hline t Stat & 0.000910889 & \\
\hline P(T<=t) one-tail & 2.015048373 & \\
\hline t Critical one-tail & 0.001821777 & 2.570581836 \\
\hline P(T<=t) two-tail & & \\
\hline t Critical two-tail & & \\
\hline
\end{tabular}

From the results of the analysis, it can be seen, among others:

1. The Mean column shows the average difference in the level of the medium road speed and the number of accidents.

2. Because $t$ counted $>t$ table $(2.57058>2.01504)$ then ho is rejected. Subsequently, Ha is accepted, meaning that there is an influence on the level of the average speed of the road to the number of accidents.

3. The value of P-value $<0.05(\alpha=5 \%)$, then the results of the hypothesis, can be said to be significant.

4. The participant's attitudes towards speeding are 38.45. The 17 shows a pessimistic attitude, 68 shows the most positive attitude towards speeding, while the impartial attitude is 42.5 .

The middle attitude of 38.52 shows, an attitude is below the neutral attitude meaning the participant has an unwilling attitude towards speeding, generally, they agree on things are harmful to speeding, normatively participants have the norm value of the people who are essential in the immediate vicinity with a mean value of 10.5 , which is below the midpoint (12.5), in general. The people around the respondents also have the belief speeding is a negative thing, relative to the views of the participants. When viewed from their perceptions of the risk of the mean value of the overall participants 19.5 , which is above the neutral point of 17.5 means that they perceive the risk of speeding to be quite high. The participants revealed the possibility of an accident, dangerous yourself, and others when he is 'speeding' on the highway.

Correlation and regression analysis are shown in the following table. 
Table 5. Correlations

\begin{tabular}{|c|c|c|c|c|c|c|c|c|}
\hline & & Att & Norm & RiscP & Age & Expe & Durat & Speed \\
\hline \multirow[t]{2}{*}{ Att } & Pearson Correlation & 1 & $.568 * *$ & .116 & .061 & $.155^{*}$ & .081 & .072 \\
\hline & Sig. (1-tailed) & .000 & .054 & .200 & .015 & .130 & .159 & \\
\hline \multirow[t]{2}{*}{ Norm } & Pearson Correlation & $.568 * *$ & 1 & .074 & .065 & $.140 *$ & .098 & .060 \\
\hline & Sig. (1-tailed) & .000 & & .152 & .182 & .025 & .086 & .203 \\
\hline \multirow[t]{2}{*}{ RiscP } & Pearson Correlation & .116 & .074 & 1 & -.064 & .059 & -.064 & .081 \\
\hline & Sig. (1-tailed) & .054 & .152 & & .185 & .206 & .188 & .130 \\
\hline \multirow[t]{2}{*}{ Age } & Pearson Correlation & .061 & .065 & -.064 & 1 & $.220 * *$ & .039 & $.222 * *$ \\
\hline & Sig. (1-tailed) & .200 & .182 & .185 & & .001 & .292 & .001 \\
\hline \multirow[t]{2}{*}{ Expe } & Pearson Correlation & $.155^{*}$ & $.140^{*}$ & .059 & $.220 * *$ & 1 & $.185^{* *}$ & $.155^{*}$ \\
\hline & Sig. (1-tailed) & .015 & .025 & .206 & .001 & & .005 & .015 \\
\hline \multirow[t]{2}{*}{ Durat } & Pearson Correlation & .081 & .098 & -.064 & .039 & $.185^{* *}$ & 1 & .095 \\
\hline & Sig. (1-tailed) & .130 & .086 & .188 & .292 & .005 & & .093 \\
\hline \multirow[t]{2}{*}{ Speed } & Pearson Correlation & .072 & .060 & .081 & $.222 * *$ & $.155^{*}$ & .095 & 1 \\
\hline & Sig. (1-tailed) & .159 & .203 & .130 & .001 & .015 & .093 & \\
\hline
\end{tabular}

** Correlation is significant at the 0.01 level (1-tailed).

\section{CONCLUSION}

Based on the analysis of vehicle speed distribution, most vehicles using speeds of 53-70 $\mathrm{km} / \mathrm{h}$ on national road sections. According to Indonesian Law UUD no. 38 of 2004, for the national road segment, the minimum speed required is $60 \mathrm{~km} / \mathrm{hour}$. From the results of the 85 percentile speed method, the speed value used by 85 percent of drivers on bend roads is around $40 \mathrm{~km} / \mathrm{h}$ to $50 \mathrm{~km} /$ hour. This can be indicated by heavy traffic conditions so that the average speed obtained is below the national road standard.

The city of Medan has a high rate of growth in vehicle ownership, which is $+9.8 \%$. The use of road transportation is dominated by particular vehicle users (94.20\%), where motorcycle users constitute the majority of the types of private vehicle users $(86.29 \%)$. Several traffic accidents in the city of Medan in 2017 were recorded at 1,233 incidents, with the number of accidents on the six review roads being 115 events, with 81 incidents involving motorcycle users $(70.4 \%)$. This shows that motorbike riders dominate the level of accidents on national road sections.

The effect of the speed level on the number of accidents is done by using the Independent sample T-test, which is a type of statistical test, which aims to compare the average speed of the road and the average number of accidents. The results of the T-test in a Pearson Correlation value of 0,0009 , indicating that there was a significant effect on the speed of the driver and the number of traffic accidents.

This study only looked at one variable (average road speed), which affected the number of accidents crossing for motorbike riders. More in-depth research is needed with a larger population, so results can be obtained that are close to the actual conditions. 
Based on measurements using the scale, participants' attitudes and beliefs the study showed attitudes and beliefs that tended to be negative towards' speeding 'behavior, attitudes, and opinions of the people around them as well as demonstrated a similar tendency. Research participants also displayed perceptions that led to being high in terms of the perception of the possibility of an accident caused by the behavior of speeding they did. Based on the study using correlation and regression analysis, it was concluded that there was a significant relationship between participants' attitudes to 'speeding' and subjective norms (attitudes and beliefs of the surrounding environment towards' speeding ').

\section{ACKNOWLEDGMENTS}

The data used in this article are the results of the Transportation Survey founded by Medan City Police Department, Indonesia Police Traffic Corps (KORLANTAS POLRI) through Traffic Accident Research Center (TARC).

\section{BIBLIOGRAPHY}

Badan Pusat Statistik (BPS) Kota Medan (2018): "Kota Medan Dalam Angka"”

Deery, H.A. 1999. Hazard and risk perception among young novice drivers, Journal of Safety Research. DOI: http://dx.doi.org/10.1016/S0022-4375(99)00018-3, 30(4): 225-236.

Eiksund, S. 2009. A geographical perspective on driving attitudes and behavior among young adults in urban and rural Norway, Safety Science. DOI; http://dx.doi.org/10.1016/j.ssci.208.07.034,47(4):529-536

Iversen, H.H.; Rundmo, T. 2004. Attitudes towards traffic safety, driving behaviour and accident involvement among the Norwegian public, Ergonomics. DOI: http://dx.doi.org/10.1080/00140130410001658 709, 47(5): 555-572

Kementerian Hukum Dan Hak Asasi Manusia (2009): Undang-Undang Republik Indonesia No.22 tentang Lalu Lintas dan Angkutan Jalan,

Kennedy, John B., and Neville, Adam M. (1976): Basic Statistical Method for Engineers and scientists, Harper \& Row Publisher, 129; 214p

Manalu, Gom Gom E P, Yusandy Aswad ST.MT (2013): “Analisis Kecelakaan Lalu Lintas Di Kota Tebing Tinggi”, Jurnal Teknik Sipil USU

Machin, M. A., \& Sankey, K. S. (2006). Factors influencing young drivers' risk perceptions and speeding behaviour. 2006 Australasian Road Safety Research, Policing and Education Conference, (January). Retrieved from http://eprints.usq.edu.au/2282/McCullagh, P., and Nelder, J., 1989. Generalized linear models (2nd edition). Chapman and Hall, London, U.K.

Maya D.K (2000): “Analisa Resiko Kecelakaan dengan Traffic Conflict Technique (TCT) (Studi Kasus: Jalan Layang UI - Depok)” Tugas Akhir, Fakultas Teknik Universitas Indonesia

Pignataro (1993): "Traffic Engineering Category Practice Enticehal in Englood Cliffs", New Jersey, USA

Romadhona, Prima Juanita, Sholihin Ramdhani (2017): "Pengaruh Kecepatan Kendaraan Terhadap Keselamatan Pengguna Kendaraan Bermotor Pada Simpang Tak Bersinyal", Jurnal Rekayasa Sipil, Vol 11, hal 31-40.

Sugiyanto, G. dan Santi, M.Y. (2015): "Karakteristik Kecelakaan Lalu Lintas dan Pendidikan Keselamatan Berlalulintas Sejak Usia Dini (Studi Kasus di Kabupaten 
Purbalingga)", Jurnal Ilmiah Semesta Teknika Fakultas Teknik Universitas Muhammadiyah Yogyakarta, Volume 18 No. 1, Mei 2015, hal. 65-75.

Wong, J. T., Chung, Y. S. \& Huang, S. H. (2010). Determinants behind young motorcyclists' risky riding behavior. Accident Analysis and Prevention, 42(1), 275281. https://doi.org/10.1016/j.aap.2009.08.004 
Traffic Accident Research Centre

This page is blank. 